\title{
On economical security of transport sector
}

\author{
Elena Voskresenskaya $^{{ }^{*}}$, Lybov Vorona-Slivinskaya ${ }^{2}$ and Sergey Panov $^{2}$ \\ ${ }^{1}$ Peter the Great St.Petersburg Polytechnic University, 195251, St. Petersburg, Polytechnicheskaya \\ str., 29, Russia \\ ${ }^{2}$ Saint Petersburg State University of Architecture and Civil Engineering, 190005, St. Petersburg, 2nd \\ Krasnoarmeyskaya St., 4, Russia
}

\begin{abstract}
The present article focuses on urgent issues of economic security in the transport sector. Transport is one of the most important sectors of the national economy that deals with complex economic and social challenges providing economy and people with transportation. The institutional changes implemented in Russia in the late 80 s and early 90 s affected all sectors, including transport. Shareholding and privatization led to fundamental change in the ratio of ownership forms in favor of private property (both collective and individual). The privatization-time stake on rapid creation of the competitive environment in the transport market through fragmentation of transport complexes and associations turned up to be unreasonable, since in most cases it caused a weakening of the position of domestic carriers, both in international and domestic transport market. Costs and tariffs for transportation sharply increased simultaneously with the decrease in investment and safety level of vehicles. In transport sector, the safety problem has traditionally been considered as a problem of a high accident rate, highlighting total number of road accidents and people died or injured in those accidents. The amount of studies on economic security in transport is negligible up to the present day.
\end{abstract}

\section{Introduction}

Today, security issue is paid great attention by most countries of the world. The reason is that the protection from undesired external influences and dramatic internal changes (or in other words the demand for security) is the fundamental need of both a person, a family and various associations of people, including society and a state.

The term "security" is an all-historical and all-social concept covering the entire history and future of the humanity being of vital importance for the existence of both an individual and social communities of all levels. In the modern sense, security is the condition and tendency of protecting vital interests of the society, a state or a person and all referred structures from internal and external threats. In Russia, the term "national security" has been widely used in scientific and practical context since the beginning of the 90 s. In recent years, Russian scientists have conducted numerous studies related to national security issues [1-5]. However, there is no unified definition of "national security". Transport safety is an integral part of national security, implying such a condition and protection level of

\footnotetext{
${ }^{*}$ Corresponding author: elenvoskr@mail.ru
} 
transport facilities from external and internal threats that ensures its stable operation. Previously, the authors of the present article paid particular attention to the assessment of the transport safety in Russia [6-12]. The purpose of this study is to develop a theoretical basis for the effectiveness of measures aimed at ensuring economic security and implement them at the level of transport organizations. The authors proposed a method for determining the level of economic security of transport organizations and calculated the indicators of this level. The feature of the proposed method is the interrelation with indicators of economic security at national and sectoral levels.

\section{Materials and Methods}

The subject of the research is organizations belonging to the transport complex. The topic of the study is the organizational and economic aspects of ensuring the effectiveness of measures aimed at providing the economic security of transport organizations. The principles of a systematic approach comprised in works of domestic and foreign scientists, are used as the methodological basis of the study. The study used a specific economic analysis, methods of expert assessments and mathematical statistics. The authors used regulatory legal acts, statistical data of Rosstat (Federal Service of State Statistics), domestic and foreign literature on the issues under consideration.

The economic security of the transport complex includes economic security of transport enterprises. Therefore, considering the economic security of a transport enterprise as its state, implying the possibility to elaborate an independent enterprise development strategy aimed at ensuring its reliable, cost-effective and sustainable operation, the authors propose the list of indicators reflecting the mentioned requirements, which is linked to approaches to assessing economic security both at national and sectoral levels.

The proposed assessment is based on a system of basic coefficients reflecting the "safe" state of various aspects of activities of a transport enterprise. The first coefficient is the growth intensity factor, which reflects the speed of the enterprise's development comparing to the whole industry. When the growth intensity factor is lower than 1 , there are likely reduction processes running at the enterprise. Thereat, the quantitative assessment should be supplemented with a qualitative analysis aimed at identifying the causes of low growth rates of an enterprise. When the growth intensity factor is over 1, positive trends in the development of a transport company are observed. However, when the factor significantly exceeds 1 (by more than 10\%), the questions on the state of a transport company arise, which requires additional analysis, since the experience of the past shows that such fastgrowing enterprises attract market participants and become subjects of attacks.

The wear extent of fixed production assets can be assessed based both on the traditional approach (degree of depreciation of fixed production assets, \%) and on the depreciation factor. The second approach is more preferable, since it allows comparing the state of a particular enterprise with the industry-wide condition of fixed production assets. When assessing wear extent, it is important to assess not only physical but also moral depreciation, at least by quality characteristics: high, medium, low.

The level of investment indicates renewal processes at the enterprise. It can also be evaluated in using two methods based on the investment factor.

The financial stability of a company is proposed to be assessed according to the existing methodology: based on the current liquidity factor, own working capital factor and the autonomy ratio. It is believed that this factor should lie between 1.0 and 2.0. If working capital exceeds short-term liabilities twice or more, such situation is considered undesirable, since this indicates an irrational investment and inefficient use of company's funds. 


\section{Results}

The most important indicators of the transport industry - investments and indexes of investment volumes into fixed assets, availability of fixed assets and degree of depreciation of fixed assets, transportation of freight - are presented in tables 1, 2 and 3 [13].

Table 1. Investments and indexes of actual volume of investments in fixed assets by the type of activity "Transport".

\begin{tabular}{|c|c|c|c|c|}
\hline \multirow{2}{*}{ Indicator } & \multicolumn{2}{|c|}{$\begin{array}{c}\text { Investments in fixed } \\
\text { assets, billion rub. }\end{array}$} & \multicolumn{2}{c|}{$\begin{array}{c}\text { Indexes of actual volume } \\
\text { of investments in fixed } \\
\text { capital }\end{array}$} \\
\cline { 2 - 5 } & 2015 & 2016 & 2015 & 2016 \\
\hline $\begin{array}{c}\text { Transport - totally, share by type } \\
\text { of activity }\end{array}$ & $\mathbf{1 8 6 6 . 3}$ & $\mathbf{2 0 6 3 . 6}$ & $\mathbf{9 1 . 1}$ & $\mathbf{1 0 3 . 0}$ \\
\hline Railroad transport & 339.6 & 358.5 & 91.4 & 97.3 \\
\hline Public motor transport & 11.5 & 18.1 & 82.8 & 148.2 \\
\hline Urban electric transport & 82.1 & 136.4 & 73.8 & 155.4 \\
\hline Freight motor transport & 20.6 & 22.2 & 100.7 & 100.8 \\
\hline Pipeline transportation & 715.9 & 663.0 & 93.2 & 87.1 \\
\hline Sea transport & 3.3 & 13.2 & 41.8 & In 3.7 rub. \\
\hline Inland waterway transport & 2.7 & 5.5 & 45.4 & 187.0 \\
\hline Air and space transport & 57.6 & 44.1 & 110.4 & 69.3 \\
\hline
\end{tabular}

Table 2. Availability of fixed assets and depreciation degree of fixed assets of transport organizations.

\begin{tabular}{|c|c|c|c|c|}
\hline \multirow{2}{*}{ Indicator } & \multicolumn{2}{|c|}{ Fixed assets, billion rub. } & \multicolumn{2}{c|}{ Ratio of fixed assets, \% } \\
\cline { 2 - 5 } & 2015 & 2016 & 2015 & 2016 \\
\hline $\begin{array}{c}\text { Transport - totally, share by type } \\
\text { of activity }\end{array}$ & $\mathbf{1 4 6 6 0 . 8}$ & $\mathbf{1 5 9 0 5 . 9}$ & $\mathbf{4 1 . 0}$ & $\mathbf{4 1 . 0}$ \\
\hline Railroad transport & 4407.4 & 4938.3 & 36.2 & 36.5 \\
\hline Public motor transport & 264.2 & 280.3 & 59.2 & 60.4 \\
\hline Urban electric transport & 1518.9 & 1669.5 & 17.4 & 17.1 \\
\hline Freight motor transport & 131.0 & 139.3 & 48.4 & 51.5 \\
\hline Pipeline transportation & 5099.6 & 5351.0 & 51.2 & 49.9 \\
\hline Sea transport & 88.8 & 102.8 & 38.2 & 38.8 \\
\hline Inland waterway transport & 89.9 & 95.7 & 56.8 & 56.8 \\
\hline Air and space transport & 151.9 & 210.7 & 44.3 & 41.8 \\
\hline
\end{tabular}

Table 3. Cargo transportation and freight turnover by types of transport.

\begin{tabular}{|c|c|c|c|c|}
\hline \multirow{2}{*}{ Indicator } & \multicolumn{2}{|c|}{$\begin{array}{c}\text { Freight transported, } \\
\text { million tons }\end{array}$} & \multicolumn{2}{c|}{$\begin{array}{c}\text { Freight turnover, billion } \\
\text { tons*km }\end{array}$} \\
\cline { 2 - 5 } & 2015 & 2016 & 2015 & 2016 \\
\hline $\begin{array}{c}\text { Transport - totally, share by type } \\
\text { of activity }\end{array}$ & $\mathbf{7 8 9 8}$ & $\mathbf{7 9 5 4}$ & $\mathbf{5 1 0 8}$ & $\mathbf{5 1 9 8}$ \\
\hline Railroad transport & 1329 & 1325 & 2306 & 2344 \\
\hline Motor transport & 5357 & 5397 & 247 & 248 \\
\hline Pipeline transport & 1071 & 1088 & 2444 & 2489 \\
\hline Sea transport & 19 & 25 & 42 & 43 \\
\hline Inland waterway transport & 121 & 118 & 64 & 67 \\
\hline Air transport & 1.0 & 1.1 & 5.6 & 6.6 \\
\hline
\end{tabular}

Table 4 contains the information on freight transportation and air cargo turnover. 
Table 4. Freight transportation and air cargo turnover.

\begin{tabular}{|c|c|c|c|}
\hline Indicator & 2015 & 2016 & 2017 \\
\hline Freight transported - total, mt & $\mathbf{1 . 0}$ & $\mathbf{1 . 1}$ & $\mathbf{1 . 3}$ \\
including international traffic & $\mathbf{0 . 6}$ & $\mathbf{0 . 7}$ & $\mathbf{0 . 9}$ \\
\hline Turnover - totally, billion $\mathrm{t}$ km & 5.6 & 6.6 & 7.9 \\
\hline $\begin{array}{c}\text { including international traffic } \\
\text { The share of freight turnover performed by } \\
\text { foreign air transportation to the total freight } \\
\text { turnover, \% }\end{array}$ & 4.8 & 5.8 & 7.0 \\
\hline
\end{tabular}

Elaboration of operational recommendations to improve the effectiveness of measures aimed at ensuring economic security based on the proposed scientific approaches was carried out in relation to the limited liability company "Domodedovo Airport Commercial Agency". The indicators of the economic security of this transport enterprise according to the proposed method were calculated.

For the calculation of the growth intensity factor of the airport, statistics are used on the passengers dispatched, since it is the main activity of the airport.

In 2015, the volume of departures of passengers in air transport amounted to $17,611.8$ thousand people; in 2016 - 23543.4 thousand people; in 2017 - 31346.5 thousand people. The growth rate of passenger shipments by the industry in 2016 amounted to $1.33 \%$; in 2017 to $1.77 \%$.

In 2015, the number of passengers dispatched from Domodedovo Airport was 1,337.1 thousand people, in 2016 - 4646.6 thousand people, in 2017 - 7,642.3 thousand people. The growth rate at Domodedovo Airport was $3.47 \%$ in 2016, in 2017 - 5.71\%. For comparison, in 2015, the number of passengers dispatched from Vnukovo Airport was 1,677.3 thousand people, in 2016 - 1365.0 thousand people, in 2017 - 2535.2 thousand people. The growth rate of the number of passengers dispatched from Vnukovo Airport in 2016 was $0.8 \%$, in $2017-1.5 \%$.

The lack of necessary data obstructs calculating the level of depreciation of production assets. However, considering that the main terminal of Domodedovo airport was recently reconstructed and expanded, the depreciation of fixed production assets is not in the area of danger.

In 2016 the heads of EAST-LINE group of companies invested \$180 million in erection of the new terminal. The introduction of modern technological solutions for managing the complex were included in plans to improve the infrastructure of Domodedovo airport. In 2016, total investments in the development of physical facilities of Russian airports amounted to 19,330 million rubles, which is approximately $\$ 774$ million. Since there are no data on the average annual cost of the fixed production assets of Domodedovo Airport, it is not possible to calculate the investment ratio. However, proceeding from the level of depreciation, it can be assumed that this indicator lies in the safety zone, since investments in the development of the airport were significant.

Table 5 provides the analysis of the financial sustainability indicators of LLC Domodedovo Airport Commercial Agency.

Table 5. Financial sustainability indicators.

\begin{tabular}{|c|c|c|c|}
\hline Indicator & 2016 & 2017 & $\begin{array}{c}\text { Threshold } \\
\text { value }\end{array}$ \\
\hline Autonomy ratio & 0.27 & 0.21 & 0.5 \\
\hline Fixed asset index & 2.77 & 2.36 & - \\
\hline Current liquidity ratio & 1.54 & 1.68 & $1-2$ \\
\hline
\end{tabular}

During the period under review, the value of working capital of OOO Domodedovo was negative, which characterizes a high proportion of borrowed funds in the total capital structure of OOO Domodedovo. 
The own asset autonomy ratio characterizes the company's dependence on external loans, in 2017 there was a slight decrease in this indicator by 0.06 , but in general, the autonomy ratio went beyond the threshold value of the indicator by 0.23 in 2016 and by 0.29 in 2017.

The fixed asset index characterizes the share of non-current assets in the sources of own funds. Throughout the studied period, the company does not have long-term receivables, i.e. the permanent asset index is determined by the non-current assets of the company.

The current liquidity ratio increased compared to the same period of 2016 by 0.14 . However, the current liquidity ratio does not go beyond the threshold values of the indicator.

Since the main part of current assets is short-term receivables, a further increase in liquidity indicators is associated with its growth.

Table 6 presents a summary of the economic security assessment of OOO Domodedovo Airport Commercial Agency.

Table 6. Assessment of the economic security of OOO "Domodedovo Airport Commercial Agency".

\begin{tabular}{|c|c|c|}
\hline Positive influence & Negative influence & No data \\
\hline $\begin{array}{l}\text { K1 - growth intencity } \\
\text { factor }\end{array}$ & $\begin{array}{l}\mathrm{K} 8 \text { - independence of a } \\
\text { transport enterprise }\end{array}$ & $\begin{array}{l}\mathrm{K} 2 \text { - depreciation of } \\
\text { fixed assets }\end{array}$ \\
\hline K3- investment ratio & $\begin{array}{l}\text { K4 - financial stability } \\
\text { (autonomy ratio) }\end{array}$ & $\begin{array}{c}\text { K5 - technical } \\
\text { coefficient } \\
\text { независимости }\end{array}$ \\
\hline $\mathrm{K} 7$ - relative market share & & $\begin{array}{c}\text { K6 - staff } \\
\text { independence ratio }\end{array}$ \\
\hline
\end{tabular}

\section{Discussion}

The system for assessing the economic security of transport enterprises must meet the following requirements:

- compatibility, which means that the elaboration of economic security indicators of a transport enterprise should be interconnected with economic security indicators of the industry and national economy;

- measurability, which implies the possibility of a quantitative assessment of economic security level of a transport enterprise;

- generality, which means that the list of economic security indicators is the same for enterprises of various types of transport. The specific character of an enterprise is taken into account when determining the parameters (threshold values) of economic security.

Within the further research a system should be developed for assessing the economic security of a transport enterprise, which is to take into account:

- the position of the enterprise in the transport services market (growth rate; market share);

- financial stability (autonomy ratio, ratio of coverage of fixed assets);

- the state of fixed assets;

- dependence on external sources (firstly, on imported rolling stock and labor);

- dependence of senior managers of a transport organization.

The level of economic security should be assessed using two methods at the same time:

- vector method;

- graphic method

The first method allows for an integrated assessment through the system of private imbalances of economic security, the second one reflects the position of an enterprise in the "safety - danger" zone for each of the components of the target vector. 


\section{Conclusions}

The specificity of the transport complex in Russia and its special role in the national economy are determined not only by the efficiently working transport system being the factor of competitiveness of the Russian economy, but also by geopolitical characteristics of the country.

The transport system has been developed during a venerable period, yet having active state origin. In the context of globalization of the world economy, the international integration increases, whereas the competition for both trade areas and access to raw materials also grows. In this regard, it is primarily important to consider the term of "economic security" at national and sectorial levels, as well as the level of business entities.

In the real sector, there is no "safe" environment for an enterprise, therefore, the only way to be in business is to develop and counter emerging threats.

Methodological provisions and recommendations elaborated within the research, as well as the results of analysis of scientific developments in the field of economic security can be used both by heads of transport enterprises and expert analysts when assessing their strategic position in the market of transport services. The results of the analysis have allowed the authors to form a unified list of economic security indicators of a transport enterprise, interconnected with economic security indicators at the national and sectoral levels

The definition of threshold values of indicators outlining the area of economically safe state of a transport enterprise is an important problem that remains unresolved. The authors assume that this problem can be resolved through creating data banks for the successful operation of transport enterprises and the processing of obtained data by means of mathematical statistics. The formation of such a system of indicators may contribute to improving the sustainability and efficiency of transport enterprises under conditions of unstable external environment.

\section{References}

1. Belitskaya, A Legal regulation of public-private partnership, p. 191 (2012)

2. S.E. Litovchenko, M.I. Korsakova, Corporate social responsibility: public expectations (2003)

3. V.G. Varnavsky, A.V. Klymenko, V.A. Korolev, Public-private partnership: theory and practice (2010)

4. R.M. Kachalov, Economic risk Management-the basis of economic security of the region (2006)

5. V. Reznichenko, Risk management (2004)

6. E. Voskresenskaya, V. Snetkov, A. Tebryaev, Z. Askarov, MATEC Web of Conf., 106 08055 (2017)

7. E. Voskresenskaya, V. Snetkov, A. Tebryaev, E3S Web of Conf. 33, 03051 (2018) doi.org/10.1051/e3sconf/20183303051

8. E. Voskresenskaya and L. Vorona-Slivinskaya, E3S Web of Conf. 33, 03052 (2018) https://doi.org/10.1051/e3sconf/20183303052

9. E. Voskresenskaya, D. Mokhorov and A. Tebryaev, MATEC WEB OF CONF., 170, 01058 (2018) DOI https://doi.org/10.1051/matecconf/201817001058

10. E. Voskresenskaya, N. Zhilskiy and E. Shariapova, MATEC WEB OF CONF., 170, 01057 (2018) DOI https://doi.org/10.1051/matecconf/201817001057 
11. P. Khe Sun, L. Vorona-Slivinskaya, E. Voskresenskaya, IOP Conf. Ser.: Earth and Envir. Scie., 90 (2017) https://doi.org/10.1088/1755-1315/90/1/012073

12. E. Voskresenskaya, L. Vorona-Slivinskaya, S. Panov, MATEC Web of Conf., 193, 02025 (2018) doi.org/10.1051/matecconf/201819302025 